\title{
Family of Phototrophic Green Sulfur Bacteria: Chlorobiaceae Copeland, the Correct Family Name; Rejection of Chlorobacterium Lauterborn; and the Taxonomic Situation of the Consortium-Forming Species
}

\author{
Request for an Opinion
}

HANS G. TRÜPER and NORBERT PFENNIG

Institut für Mikrobiologie der GSF, 34 Göttingen, Germany

\begin{abstract}
The family of phototrophic green sulfur bacteria contains five genera: Chlorobium Nadson 1906, Pelodictyon Lauterborn 1913, Clathrochloris Geitler 1925, Chloropseudomonas Czurda and Maresch 1937, and Prosthecochloris Gorlenko 1970. Of these, Chlorobium is the type genus, and the name of the family is Chlorobiaceae Copeland 1956. The familial name Chlorobacteriaceae Lauterborn 1913 is illegitimate. Furthermore, the applications of the names Chlorobacterium Lauterborn 1916 and $C$. symbioticum Lauterborn 1916 are uncertain, and the Judicial Commission is requested to place these names in the list of rejected names. The taxonomic situation of the consortium-forming "symbiotic species" of the phototrophic green sulfur bacteria /Chlorochromatium aggregatum, Chlorochromatium glebulum, Pelochromatium roseum, and Cylindrogloea bacterifera) is discussed.
\end{abstract}

The phototrophic green sulfur bacteria presently (Bergey's Manual of Determinative Bacteriology, 7th ed.) are placed in the family Chlorobacteriaceae Lauterborn 1913. However, this family name is illegitimate because, when originally proposed, it was not based on one of the contained genera, which were Chlorochromatium, Pelodictyon, Schmidlea, Pelogloea, and Pelochromatium. Subsequent to the publication of the familial name Chlorobacteriaceae, Lauterborn (9) published the generic name Chlorobacterium. However, this does not render the name Chlorobacteriaceae legitimate.

Chlorobacterium Lauterborn 1916 is ordinarily cited as the type genus of the family Chlorobacteriaceae Lauterborn 1913. However, this is not possible, for by definition the type of a family is the genus on whose name the family is based. Obviously the name Chlorobacteriaceae could not have been based on the genus Chlorobacterium, because the genus was not described until 3 years after the family name had been given! It appears that the generic name was derived from the familial name instead of vice versa.
Furthermore, there is some question concerning the legitimacy of the generic name Chlorobacterium Lauterborn itself. It appears from Lauterborn's description that the only species of this genus, C. symbioticum, is an obligately symbiotic microorganism living as an outer cover of certain protozoa such as amoebae and flagellates. Lauterborn classified this green organism as a phototrophic sulfur bacterium, although neither the presence of hydrogen sulfide in the original habitats nor the oxidation of hydrogen sulfide by the cells to extracellularly deposited elemental sulfur was mentioned. Furthermore, no evidence was given to show the presence of bacteriochlorophyll or other photosynthetic pigments. The light dependance of growth was also not shown. Finally, there was not even proof presented to show that this green microorganism is a bacterium. Significantly enough, van Niel, in Bergey's Manual (18), put a question mark behind the word "bacteria" in the description of this organism. The reason for the very limited knowledge about this organism is that, since Lauterborn's original description, no 
other observations of the organism have been reported. It is quite clear, then, that the applications of the names Chlorobacterium and C. symbioticum Lauterborn are uncertain. The Judicial Commission is therefore requested to place these nomina dubia on the list of rejected names.

At present, the phototrophic green sulfur bacteria are placed in five genera: Chlorobium Nadson 1906, Pelodictyon Lauterborn 1913, Clathrochloris Geitler 1925, Chloropseudomonas Czurda and Maresch 1937 (15), and Prosthecochloris Gorlenko 1970. Of these, only Chlorobium has had a family name based on it. Thus, Chlorobiacea (sic) Copeland 1956 (here corrected to Chlorobiaceae) is the correct name of the family of phototrophic green sulfur bacteria containing the five genera cited above. That Chlorobium is the type genus of this family is especially fortuitous, because this genus contains the most widespread and best known species (free living and all studied in pure culture) of the phototrophic green sulfur bacteria.

Besides Chlorobacterium Lauterborn, four other symbiotic forms of phototrophic sulfur bacteria have been described (none was ever grown in pure culture). All of these, however, were named as consortia. By "consortium" is meant an aggregate or association of two different organisms. Species names were applied to the consortium rather than to one of the two components. Because this nomenclature clearly violates Rule 14a (3) of the International Code of Nomenclature of Bacteria, the names of these consortia have to be considered as not validly published, i.e., "without standing in nomenclature." The names of the consortia may be used as laboratory designations, but they are without taxonomic value or importance.

The present knowledge about the consortia is roughly summarized below (see also Bergey's Manual, 7 th ed.).

Consortium "Chlorochromatium aggregatum" Lauterborn 1906. The consortium consists of a rather large colorless polar flagellate bacterium as the center which is surrounded by green bacteria, arranged in four to six rows from two to four cells high. The consortium is motile and multiplies by the more or less simultaneous fission of its components. In vivo spectra of enrichment cultures show maxima typical for chlorobium chlorophylls (bacteriochlorophylls $c$ or $d$ ). This consortium is identical with the Chloronium mirabile of Buder (1). Mechsner (10) described the isolation of the green component and named it Chlorobium chlorochromatii. His isolate was lost before extensive comparative studies with other Chlorobium species could be done. The culture conditions used by Mechsner did not allow growth of the entire consortium. More recently, the enrichment culture of the consortium has been reported (13). At present, there is little doubt that the green component is indeed a member of the genus Chlorobium.

Consortium "Chlorochromatium glebulum" Skuja 1956. This aggregate is similar to the "Chlorochromatium aggregatum" consortium, but the cells of the green component contain gas vacuoles, and Skuja (16) states morphological similarity of the green component with Pelodictyon luteolum (synonym P. aggregatum). Since the consortium has never been grown in enrichment or pure culture, there is no experimental evidence that the green component belongs to the Chlorobiaceae.

Consortium "Pelochromatium roseum" Lauterborn 1913. The aggregate is similar to the "Chlorochromatium aggregatum" consortium, except that the outer cells are not green but pinkish brown in color. This color is very similar to that of pure cultures of two newly described pinkish brown Chlorobium species (14). The similarity is substantiated by the identity of the in vivo absorption spectra (bacteriochlorophyll $d$ and carotenoids of group 5) of enrichment cultures of the consortium and of pure cultures of the brown Chlorobium species. The consortium has been enriched by using a sulfide-containing culture medium (13). All these characteristics leave little doubt that the brown component of the consortium may belong to Chlorobiaceae. Utermöhl (17), studying natural samples, suggested the name Lauterborniola minima for the brown component, which he thought to belong to the Phaeobacteria; he named the central organism Endosoma palleum. The taxonomic significance of Utermöhl's suggestions remains to be evaluated.

Consortium "Cylindrogloea bacterifera" Perfiliev 1914. The consortium was described to consist of a central filamentous nonmotile bacterium embedded in a large slime capsule, which is covered by a layer of green bacteria. The green component is described to contain a chlorophyllous pigment not identical with plant chlorophyll or bacteriochlorophyll $a$. Skuja (16) depicted the green component as containing gas vacuoles. It seems likely that this consortium is a variety of the Chlorochromatium consortia. The green component might be a Chlorobium or Pelodictyon species. 


\section{LITERATURE CITED}

1. Buder, J. 1914. Chloronium mirabile. Ber. Deut. Bot. Ges. 31:80-97.

2. Czurda, V., and E. Maresch. 1937. Beitrag zur Kenntnis der Athiorhodobakterien-Gesellschaften. Arch. Mikrobiol. 8:99-124.

3. Copeland, H. F. 1956. The classification of lower organisms. Pacific Books, Palo Alto, Calif.

4. Geitler, L., and A. Pascher. 1925. Cyanochloridinae-Chlorobacteriaceae, p. 451-463. In A. Pascher (ed.), Die Süsswasserflora Deutschlands, Österreichs und der Schweiz G. Fischer, Jena.

5. Gorlenko, V. M. 1970. A new phototrophic green sulphur bacterium Prosthecochloris aestuari nov. gen. nov. spec. Z. Allg. Mikrobiol. 10:147149.

6. International Code of Nomenclature of Bacteria. 1966. Int. J. Syst. Bacteriol. 16:459-490.

7. Lauterborn, R. 1906. Zur Kenntnis der sapropelischen Flora. Allg. Bot. Z. 12:196-197.

8. Lauterborn, R. 1913. Zur Kenntnis einiger sapropelischer Schizomyceten Allg. Bot. Z. 19:97-100.

9. Lauterborn, R. 1916. Die sapropelische Lebewelt. Ein Beitrag zur Biologie des Faulschlammes natürlicher Gewässer. Verh. Natur. Med. Ver. Heidelberg 13:395-481.

10. Mechsner, K. 1957. Physiologische und morphologische Untersuchungen an Chlorobakterien. Arch. Mikrobiol. 26:32-51.
11. Nadson, G. A. 1906. The morphology of inferior algae III. Chlorobium limicola Nads., the green chlorophyll bearing microbe (Russian). Bull. Jard. Bot. St. Pétreb. 6:190.

12. Perfiliev, B. V. 1914. On the theory of symbiosis of Chlorochromatium aggregatum Lauterb. (Chloronium mirabile Buder) and Cylindrogloea bacterifera nov. gen., nov. spec. (Russian). J. Mikrobiol. 1:223.

13. Pfennig, N. 1967. Photosynthetic bacteria. Annu. Rev. Microbiol. 21:285-324.

14. Pfennig, N. 1968. Chlorobium phaeobacteroides nov. spec. und $C$. phaeovibriodes nov. spec., zwei neue Arten der grünen Schwefelbakterien. Arch. Mikrobiol. 63:224-226.

15. Pfennig, N., and H. G. Trüper. 1969. Proposal to declare Rhodopseudomonas palustris and Chloropseudomonas ethylica as nomina conservanda. Int. J. Syst. Bacteriol. 19: 153-154.

16. Skuja, H. 1956. Taxonomische und biologische Studien über das Phytoplankton schwedischer Binnengewässer. Nova Acta Regiae. Soc. Sci. Upsal. Ser. IV 16:1-104.

17. Utermöhl, H. 1924. Phaeobakterien (Bakterien mit braunen Farbstoffen). Biol. Zentralbl. 43:605-610.

18. van Niel, C. B. 1957. Suborder I. Rhodobacteriineae Breed, Murray and Hitchens, 1944, p. 35-36. In R. S. Breed, E. G. D. Murray, and N. R. Smith (ed.), Bergey's manual of determinative bacteriology, 7 th ed. The Williams \& Wilkins Co., Baltimore. 